\title{
Mice deficient for PDGF B show renal, cardiovascular, and hematological abnormalities
}

\author{
Per Levéen, ${ }^{1}$ Milos Pekny, ${ }^{1}$ Samuel Gebre-Medhin, ${ }^{1}$ Birgitta Swolin, ${ }^{2}$ Erik Larsson, ${ }^{3}$ \\ and Christer Betsholtz ${ }^{1}$ \\ ${ }^{1}$ Department of Medical Biochemistry, University of Göteborg, S-413 90 Göteborg, Sweden; ${ }^{2}$ Department of Clinical \\ Chemistry, Sahlgrenska Hospital, S-413 45 Göteborg, Sweden; ${ }^{3}$ Department of Pathology, University of Uppsala, S-751 85 \\ Uppsala, Sweden
}

Platelet-derived growth factor (PDGF) affects the growth, migration, and function in vitro of mesenchymal cells, but little is known about its normal physiological functions in vivo. We show here that mice deficient for PDGF B die perinatally and display several anatomical and histological abnormalities. Kidney glomerular tufts do not form, apparently because of absence of mesangial cells. Instead, a single or a few distended capillary loops fill the glomerular space. The heart and some large arteries dilate in late-stage embryos. Most PDGF B mutant embryos develop fatal hemorrhages just prior to birth. Their hematological status includes erythroblastosis, macrocytic anemia, and thrombocytopenia. On the basis of these findings, we conclude that PDGF B has crucial roles in vivo in establishing certain renal and circulatory functions.

[Key Words: PDGF; gene knockout; glomerulus development; mesangial cells; cardiac dilation; anemia; thrombocytopenia; erythroblastosis]

Received May 30, 1994; revised version accepted July 7, 1994.

Platelet-derived growth factors (PDGFs) comprise a family of mitogens for connective tissue cells such as smooth muscle cells, fibroblasts, and glia cells (for review, see Raines et al. 1990). Besides growth, the cellular effects of PDGFs include chemotaxis (Grotendorst et al. 1982; Siegbahn et al. 1990), differentiation (Raff 1989; Richardson 1990), and modulation of other cell functions such as the production of extracellular matrix components (Owen et al. 1982; Majack et al. 1985) and contraction (Berk et al. 1986; Gullberg et al. 1990). Following its identification as a secretory product of platelets (Balk 1971; Busch et al. 1976), PDGFs have been shown to be synthesized by numerous normal cell types, including endothelial cells, monocytes/macrophages, smooth muscle cells, fibroblasts, placenta cytotrophoblasts, neurons, and certain glial cells (for review, see Heldin and Westermark 1990; Raines et al. 1990; Raines and Ross 1993). Whereas PDGF expression in megakaryocytes and neurons (Sasahara et al. 1991, 1992; Yeh et al. 1991) appears to be constitutive, expression in other cell types generally accompanies functional or mitogenic activation (for review, see Betsholtz 1993).

The PDGF family includes three dimeric ligands, PDGF AA, AB, and $B B$, constituted from two polypeptide chains, PDGF A and B, encoded by different genes (Heldin and Westermark 1989). According to the current model of PDGF ligand-receptor interaction, the PDGF receptor type- $\alpha$ (PDGFR $\alpha$ ) binds the A- or the B-chain of the PDGF dimer with high affinities, whereas the PDGF receptor type- $\beta$ (PDGFR $\beta$ ) only binds the B-chain. PDGF receptor dimerization occurs as a result of PDGF binding and appears to be a prerequisite for signal transduction across the plasma membrane (Heldin et al. 1989). Consequently, the receptor dimer specificity for PDGF AA is $\alpha \alpha$, for PDGF AB either $\alpha \alpha$ or $\alpha \beta$, and for PDGF BB $\alpha \alpha$, $\alpha \beta$, or $\beta \beta$ (Hart et al. 1988; Heldin et al. 1988; Seifert et al. 1989).

In the adult, most of the proposed functions of PDGF relate to different responses to injury, for example, inflammation and wound healing (Ross et al. 1986; Heldin and Westermark 1990). PDGF has also been functionally implicated in numerous pathological conditions, including connective tissue overgrowth in conjunction with chronic inflammatory processes, atherosclerosis, fibrosis, and tumor stroma formation (Raines and Ross 1993). Expression of PDGF B and PDGFR $\beta$ in mesangial cells of the kidney glomerulus suggests a role of this ligandreceptor pair at this site (Abboud et al. 1987; Shultz et al. 1988; Silveer et al. 1989). Glomerulonephritis, which often involves extensive mesangial cell proliferation, may be associated with increased expression of PDGF B and PDGFR $\beta$ in the glomeruli (Fellström et al. 1989; Iida et al. 1991).

PDGF is also thought to be important in mammalian embryogenesis. mRNAs for PDGF A and PDGFR $\alpha$ are coexpressed in mouse preimplantation embryos, sug- 
gesting autocrine regulation of growth, or other functions, at these stages (Mercola et al. 1988; Rappolee et al. 1988). Following implantation, the expression of PDGF $A$ and PDGFR $\alpha$ appears to be separated in different layers of embryonic tissues (Orr-Urtreger and Lonai 1992), suggesting paracrine signaling. Extraembryonic expression of PDGF B and PDGFR $\beta$ has been demonstrated in the human placenta at early and late gestation (Goustin et al. 1985; Holmgren et al. 1991).

Ideas concerning the functions of PDGF in vivo are primarily based on the expression patterns of PDGF ligands and receptors and their changes under physiological and pathological conditions. Additional clues to PDGF function in vivo could be obtained through lossof-function analyses. Toward this end, we have generated mice carrying a null mutation in the gene encoding the PDGF B-chain, which are therefore deficient with regard to $P D G F B B$ and $A B$. The phenotypes of these mice include abnormal kidney glomeruli, heart and blood vessel dilation, anemia, thrombocytoponia, and hemorrhages and lead to perinatal death.

\section{Results}

Mutagenesis of the PDGF B-chain gene

The PDGF B gene consists of seven exons separated by differently sized introns. The major part of the mature PDGF B protein is coded by exons 4 and 5 (Fig. 1A). The tertiary structure of PDGF BB is dependent on intramolecular disulfide bridges, of which those between cysteine residues 1 and 6 , as well as 3 and 7, respectively, have been shown to be necessary for the bioactivity of PDGF BB (Giese et al. 1987; Sauer and Donoghue 1988; Östman et al. 1992; Heldin et al. 1993). To generate a null mutation, we designed a targeting vector that would delete part of exon 3 and the entire exon 4 (Fig. 1B). This should abolish the function of PDGF by preventing the formation of a major part of the mature PDGF BB molecule, including cysteine residues involved in all interand intramolecular S-S bridges. The targeting construct was transfected into the 129SV mouse embryonic stem (ES) cell line E14.1 (Kün et al. 1991) and G418-resistant clones were selected. Southern blot analysis showed that
Figure 1. The PDGF $B$ gene targeting strategy. (A) Schematic presentation of the mature PDGF BB dimer and its parts encoded by exons 3,4 , and 5 . The position of individual cysteine residues $(\mathrm{C})$, as well as the disulfide bridges, are indicated as determined from the the crystal structure of PDGF BB (Oefner et al. 1992) and by cysteine mutagenesis studies (Östman et al. 1992). Shaded areas represent the theoretic deleted coding capacity of the PDGF null allele. $(B)$ Strategy for the PDGF B knockout and discrimination between wild-type and null alleles using Southern blot analysis. Numbered boxes illustrate the exons of the PDGF B gene. Restriction sites are indicated that delineate the construct and probe and that are used in the Southern blot analysis. (R) EcoRI; (H) HindIII; (X) Xhol.
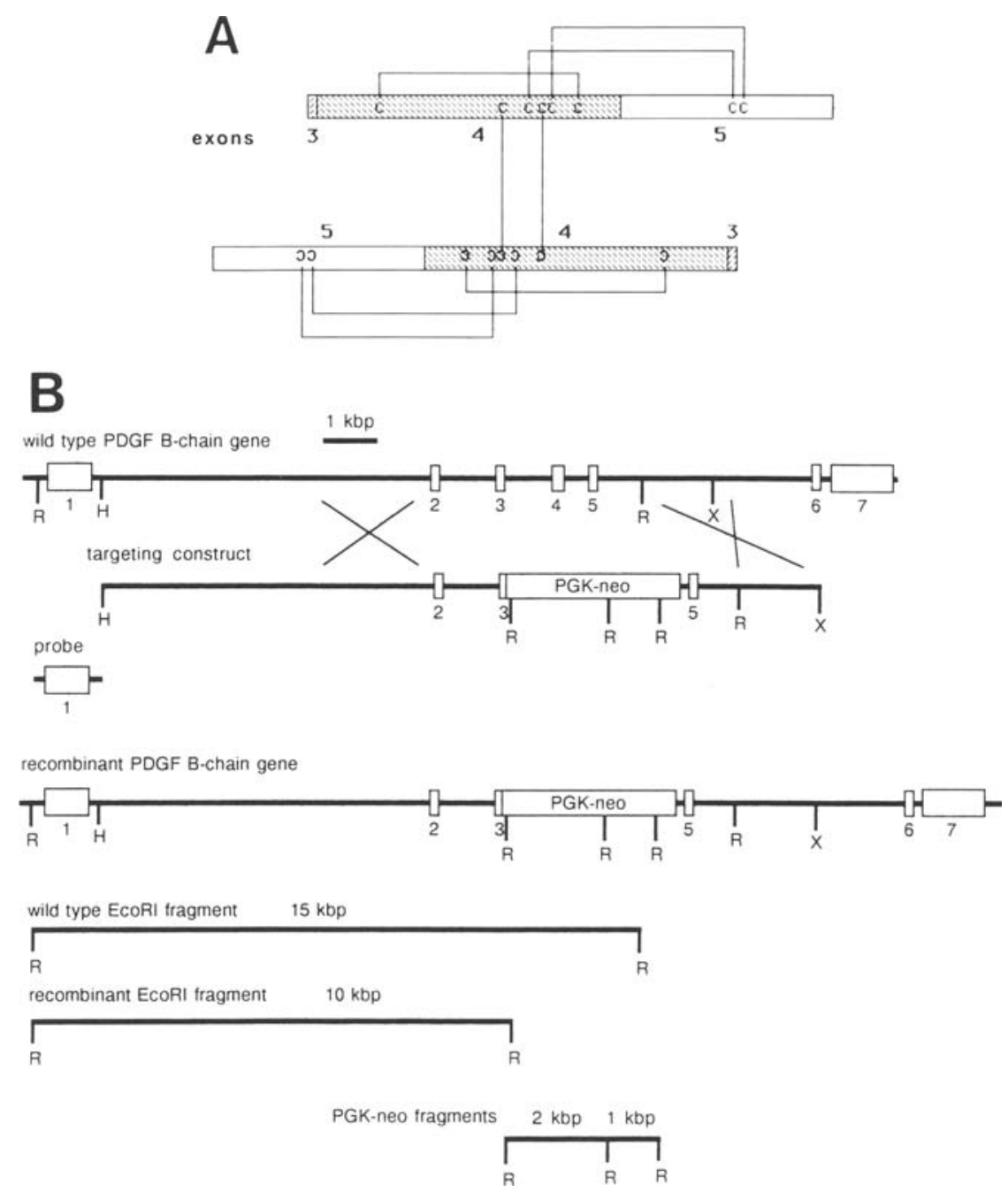
$\sim 10 \%(32 / 327)$ of the G418-resistant cell clones had undergone homologous recombination. Four of these were selected for injection into $\mathrm{C} 57 \mathrm{Bl}$ blastocysts to generate 129SV/C57Bl mouse chimeras. PDGF B + / - /heterozygous) offspring was generated by chimeras derived from two of the ES cell clones, 3.22 and 3.39. Using an exon 4-specific probe, we could demonstrate that both the 3.22 and the 3.39 mutant PDGF B alleles lacked exon 4 (Fig. 2A). Thus, the targeting construct was integrated by a replacement mechanism in both clones. Hybridization using a neo probe showed that clone 3.22 had the PDGF $B$ exon 3-4 region replaced by a concatamer of $\sim 50$ cop-

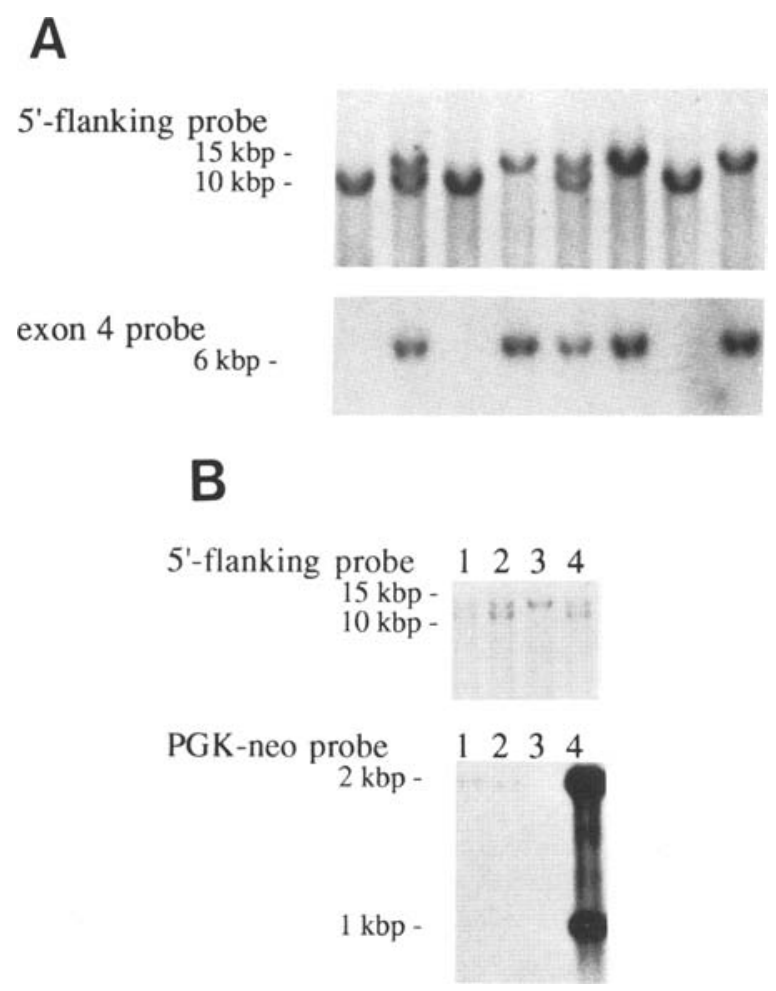

Figure 2. Genotype analyses. (A) Southern blot analyses of DNA from mid-gestational embryos from a cross between PDGF B +1 - mice. In this case, the male carried the 3.22 allele and the female the 3.39 allele. Individuals that are homozygotes with regard to the targeted allele $(1,3$, and 7$)$ lack hydridization to a PDGF B exon 4-specific probe proving that both the 3.22 and the 3.39 allele lack PDGF B exon 4 and, therefore, both have originated via a replacement mechanism. $(B)$ Characterization of the 3.39 (lanes 1,2) and 3.22 (lane 4) alleles. (Top) Hybridization to the $5^{\prime}$-flanking probe indicating heterozygous genotypes in lanes 1,2, and 4. Hybridization with a neo probe (bottom) shows that whereas the 3.39 allele has integrated a single copy of the neo cassette, the 3.22 allele has integrated $\sim 50$ copies of the neo cassette. In animal crosses the neo hybridization pattern always segregated with the targeted allele (not shown), providing evidence that the 3.39 allele was created by a single copy replacement, as illustrated, whereas the 3.22 allele was created by homologous integration of a large concatamer of the targeting construct, however, via a replacement mechanism, as the endogenous exon 4 sequence was deleted (Fig. 1A).
Table 1. Genotypes of litters obtained by intercrossing $P D G F B+1-$ mice

\begin{tabular}{lllll}
\hline \multirow{2}{*}{$\begin{array}{l}\text { Number of } \\
\text { litters }\end{array}$} & Age & \multicolumn{3}{c}{ Embryos (no. $)^{\mathrm{a}}$} \\
\cline { 3 - 5 } Before birth & & 5 & 12 & 5 \\
2 & E11.5 & 6 & 11 & 2 \\
2 & E14.5 & 8 & 24 & 12 \\
5 & E16.5 & 13 & 31 & $18(2)$ \\
8 & E17.5 & 25 & 49 & $23(10)$ \\
12 & E18.5 & 25 & 46 & $16(15)$ \\
10 & E19 & 82 & 173 & 76 \\
$\quad$ Total & & 58 & 126 & 0 \\
After birth & & & & \\
26 & $1-30$ days & 58 &
\end{tabular}

${ }^{a}$ The number of $-1-$ embryos of each age group that displayed hemorrhages at the time of ceasarean section are in parenthesis.

ies of the targeting construct, whereas clone 3.39 had undergone replacement with a single copy of the targeting construct (Fig. 2B). PDGF B heterozygotes from both clones were found to be fertile and at up to 10 months of age, free of detectable clinical problems. PDGF B-1(mutant) offspring was generated by intercrossings of heterozygotes, and the phenotypical effects of PDGF B deficiency were studied in hybrid 129SV/C57Bl genetic background. All phenotypical abnormalities described below were found in both 3.22 and 3.39 mutants.

\section{Perinatal lethality of PDGF B mutant mice}

No PDGF B mutants were found in 26 litters from heterozygous crossings, with a total of 184 pups aged 1 postnatal day or more. The ratio between heterozygotes and wild type $(+1+)$ was $126: 58$, which is close to the theoretical 2:1 ratio expected if death of all PDGF B mutants occurred before analysis. We then analyzed 331 embryos of different prenatal ages (embryonic day 11.5 (E11.5)E19]. Here, the ratio between the prenatal wild-type and heterozygous and mutant genotypes was $\sim 1: 2: 1$, suggesting that all mutant embryos survive E11.5 (Table 1). However, 12 of the mutant E17.5-18.5 embryos were dead or dying and appeared hemorrhagic and edematous (Fig. 3A). Postnatal analysis of mutant individuals proved difficult because a majority of them were eaten by the mothers shortly after birth. To distinguish between the possibilities that most PDGF B mutants are born alive and subsequently killed and eaten by their mothers, versus the possibility that they die spontaneously perinatally, we delivered a total of 87 pups by cesarean section at E19, 0-16 hr before the expected time of birth. Of the 16 mutants found in this group, 4 were dead and had the hemorrhagic and edematous phenotype. The remaining 12 were alive. Eleven of these had subcutanous hemorrhages located primarily to the neck, scapular, and flank regions and over the dorsal spinal processes (Fig. 3B-D). None of the 12 mutant embryos, alive at the time of cesarean section, started to breathe 

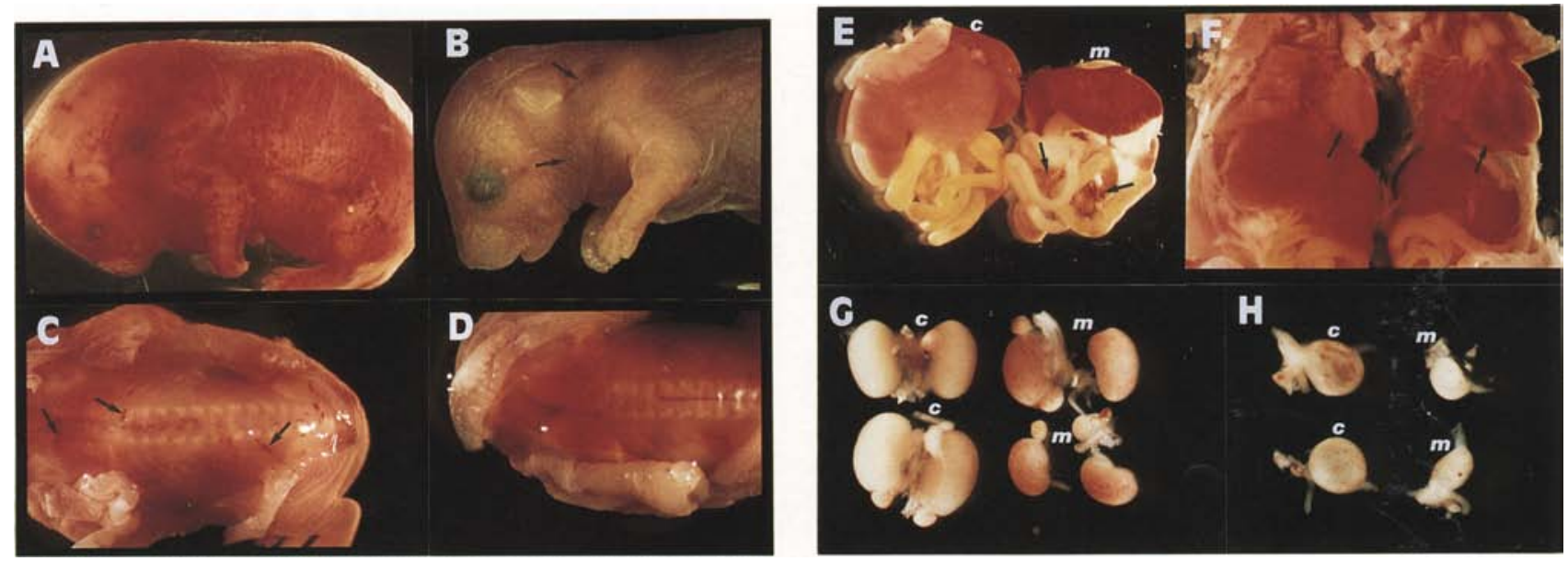

Figure 3. Anatomical findings in PDGF B mutant embryos. $(A)$ The typical external features of a dead E18.5 mutant embryo. Note the hemorrhagic and edematous appearance. The possibility exists that this particular phenotype reflects a mixture of primary (attributable to PDGF B deficiency) and secondary (postmortal) changes. (B) External appearance of a live mutant E19 embryo. Note the localized subcutaneous purpura (arrows). $(\mathrm{C}-\mathrm{H})$ Findings in E19 PDGF B mutant $(\mathrm{m})$ and control (c) embryos alive at the time of cesarean delivery, killed by decapitation, and dissected under the microscope. $(C)$ Localized bleeding (arrows) under the skin and in the brown fat of a mutant E19 embryo. (D) Corresponding appearance of a normal E19 embryo. (E) Abdominal organs of an E19 control (C) and a mutant $(\mathrm{m})$ embryo. Note the hemorrhages in the liver and the dilated mesenteric blood vessels (arrows). (F) Thoracic and abdominal organs of an E19 control (left) and mutant (right) embryo. The hearts (arrows) were still beating in these decapitated embryos, and the photograph was taken at a time point when both the control and the mutant hearts were in the diastolic phase. (G) The spotty kidney phenotype of two pairs of E19 mutant $(\mathrm{m})$ kidneys in comparison with two pairs of control (c) kidneys. $(H)$ Urinary bladders from two control (c) and two mutant (m) E19 embryos.

regularly under conditions that allowed 65 of the 71 heterozygous or wild-type littermates to do so. After having grasped for air a few times, the mutants stopped breathing and died. In summary, it appears that the majority (approximately three-fourths) of the PDGF B mutants die at birth, whereas approximately one-fourth die 1-2 days prior to birth (E17-18.5).

\section{Anatomical/pathological findings in PDGF B mutant embryos}

Dissection of PDGF B mutant and control embryos revealed several consistent differences. Most of the live E19 but, less frequently, younger, mutants demonstrated hemorrhages in subcutanous regions, periscapular brown fat and the liver (Fig. 3C,E and Table 1). Although hemorrhages in these regions were regularly found in E19 mutants, none of the sites were obligatory. For example, in some cases with extensive skin hemorrhages, the liver and brown fat was not affected.

Mutant embryos, E17.5 and older, displayed enlarged and deformed hearts and dilated thoracic large arteries (Fig. 3F), reduced liver volume (Fig. 3E,F), spotty and reduced size kidneys (Fig. 3G), and empty urinary bladders (Fig. $3 \mathrm{H}$ ). In addition, dilated blood vessels were found in the mesenterium of most mutants (Fig. 3E).

\section{Abnormal glomeruli in PDGF B mutant embryos}

The "spotty kidney phenotype" was evident in all mutant embryos, aged E17.5 or older. Histological sections demonstrated that these red spots reflected abnormally developed glomeruli. The capillary tuft of the normal mature glomerulus was missing and, instead, the Bowman's capsule space contained one or several capillary aneurysm-like structures filled with blood (Fig. 4) This malformation was very distinct and affected all "mature" glomerular bodies seen in the inner part of the cortex. The total number of glomerular bodies in the mutant kidneys was, however, similar to that of heterozygous and wild-type kidneys.

Using electron microscopy (Fig. 5), the aneurysm-like structures were demonstrated to be delimited by basement membranes, with morphologically distinctive podocytes on its outer surface (facing the Bowman's space) and endothelial cells lining its inside. In the glomerular tufts of wild-type or heterozygous animals, mesangial cells were abundant between the capillary loops (Fig. 5A). Mesangial cells, however, could not be identified by electron microscopy in glomerular bodies of mutant embryos (Fig. 5B) and were therefore either absent or severely reduced in number.

We have not been able to reveal any consistent morphological abnormalities of the early immature glomeruli in the PDGF B mutant kidneys. The "comma" and S-shaped immature glomeruli were always indistinguishable in appearance and number between mutant and control animals (Fig. 4A,B). In a proportion of later stage glomerular vesicules, however, the central core of mesenchymal cells, possibly representing mesangial progenitors, was absent and replaced by a blood-filled cavity (cf. Fig. 4, C and D). 

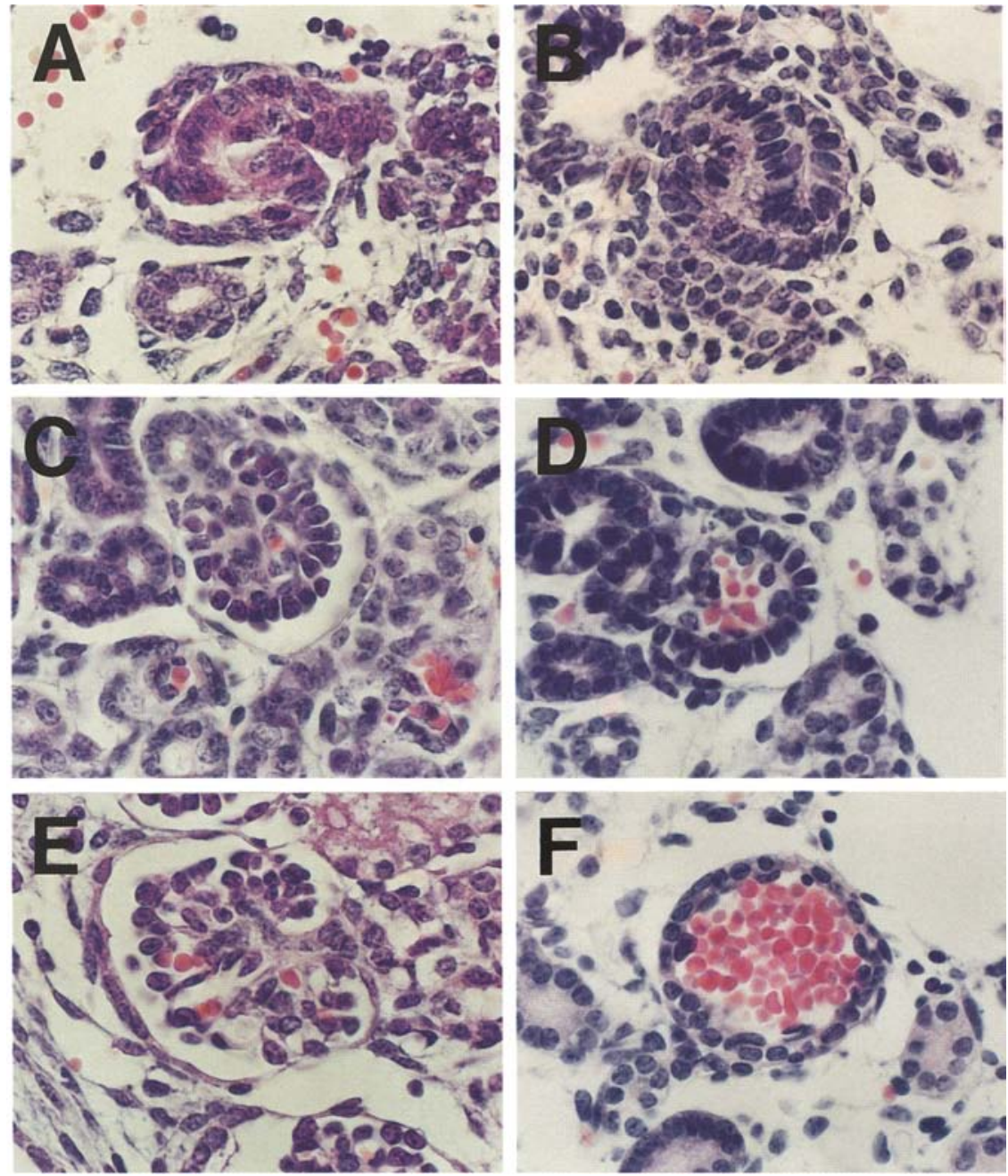

Figure 4. The kidney glomerulus phenotype. Development of glomeruli in heterozygous $(A, C, E)$ and mutant $(B, D, F)$ kidneys from E18.5 embryos. $(A, B)$ S-shaped immature glomerular bodies from the outer kidney cortex. $(C, D)$ Developing glomeruli from the middle part of the cortex. Note the absence of cells in the central part of the developing mutant glomerular tuft. $(E, F)$ Mature glomerular bodies from the inner part of the cortex. In the mutant structure, the glomerular tuft is replaced by a capillary aneurysm.

\section{Heart and blood vessel dilation in PDGF B mutant embryos}

Histological examination of the thoracic region of E16.5-E19 embryos revealed that the heart enlargement seen anatomically reflected dilation affecting both ventricles (Fig. 6). The aorta was dilated too and had a cross section area approximately twice the normal size (Fig. 6). The aortic muscular wall was extended and consequently thinner, but the number of smooth muscle cell layers appeared to be normal; thus, there were no signs of hypoplasia or hypotrophy. General stainings for elastic membranes (elastin van Gieson and aldehyde fuchsin) and collagens (sirius red) have not revealed any significant differences in the content or distribution of these extracellular matrix components in the aortic walls of the mutant versus control embryos (data not shown).

Heart and blood vessel dilation was even more pronounced in the proportion of the PDGF B mutant embryos dying at E17-E18.5, in which extreme dilation of all chambers of the heart and of the thoracic aorta was seen (Fig. 7A-F). Also in these individuals, the arterial wall contained the normal number of smooth muscle cell layers. Apart from being dilated, the hearts of this group of mutant embryos showed regions of the right ventricle that were hypertrabeculated and abnormally thin-walled. Areas were found in which the ventricular lumen and the pericardial space were separated by a single cell layer (Fig. 7C). In the left ventricle, subpericardial blood vessels were found to be dilated and congested (Fig. 7D), indicating, together with the overall signals of blood vessel stasis and the generalized subcutaneous edema, severe heart failure.

\section{Anemia with erythroblastosis and thrombocytopenia in PDGF B mutant embryos}

A noticeable increase in nucleated erythrocytes was seen in tissue sections from PDGF B mutant embryos. To reveal details concerning the hematological profile in PDGF B mutant and control embryos, blood was collected from decapitated E19 embryos and subjected to a series of routine analyses. The results, summarized in Table 2, are consistent with macrocytic anemia with erythroblastosis and thrombocytopenia. The number of 

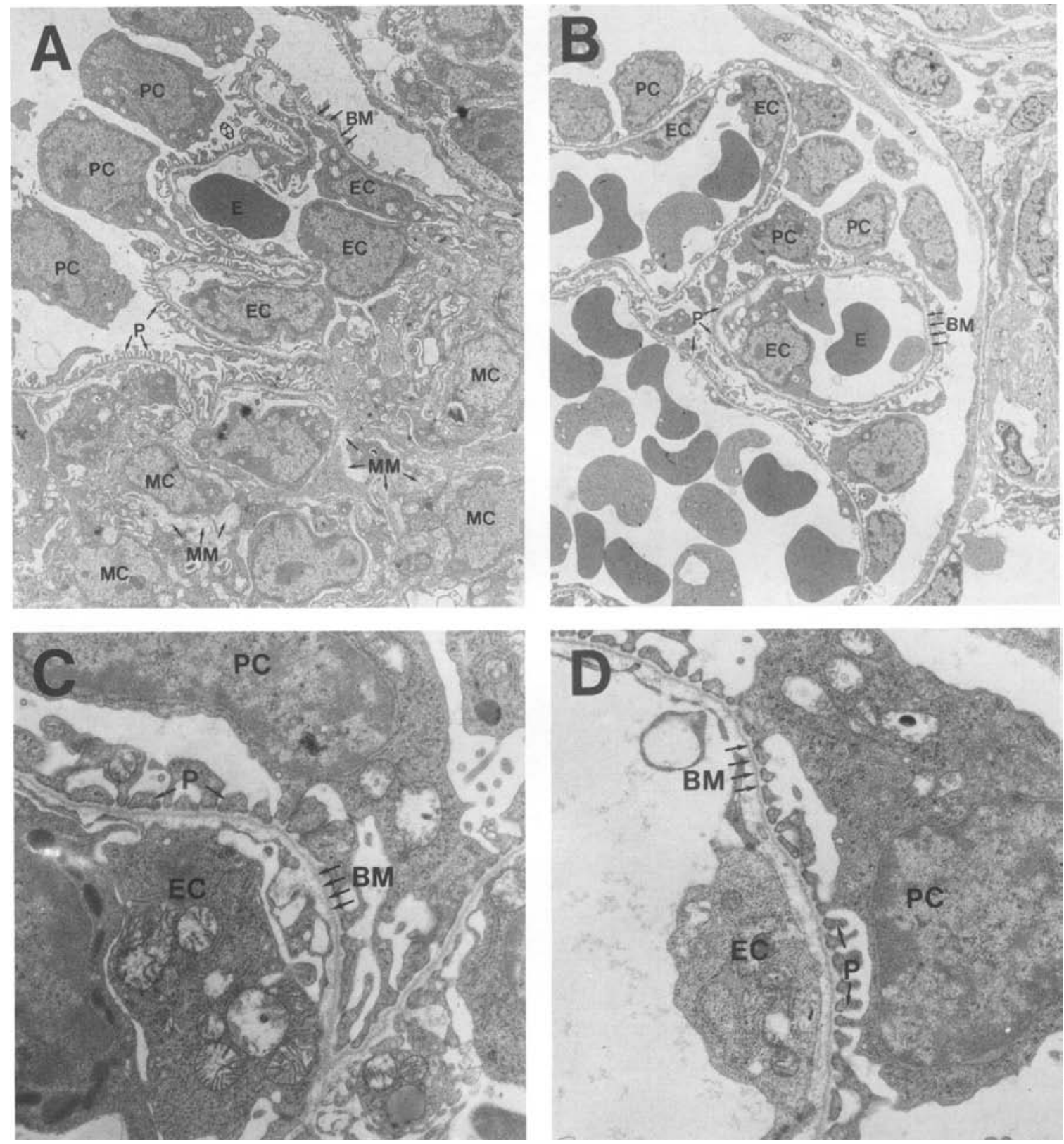

Figure 5. The kidney glomerulus phenotype. Electron microscopic examination of PDGF B heterozygous $(A, C)$ and mutant $(B, D)$ glomerular structures. Note the presence of mesangial cells $(\mathrm{MC})$ and mesangial matrix $(\mathrm{MM})$ in the normal glomerulus $(A)$ and their absence in the mutant glomerular structure $(B)$ The basement membrane $(\mathrm{BM})$ between podocytes $(\mathrm{PC})$ and endothelial cells $(\mathrm{EC})$ is similar in its appearance in the two structures. $(A, B)$ Magnification, $600 \times ;(C, D) 400 \times$. (E) Erythrocytes; $(\mathrm{P})$ podocytic foot processes.

erythroblasts calculated per 100 leukocytes was increased significantly in PDGF B mutants, and anemia was demonstrated by means of reduced hemoglobin values and hematocrits. The mean erythrocyte corpuscular volume was increased by $\sim 20 \%$. Thrombocyte counts were reduced to $\sim 15 \%$ in PDGF B mutants compared with heterozygous and wild-type embryos (Table 2). No significant differences were found between mutants and controls regarding the frequency of granulocytes, lym- phocytes, and monocytes in differential counts /data not shown).

\section{Discussion}

The glomerulus phenotype of PDGF B mutants involves failure of mesangial cells

Mesangial cells in the glomerulus are known to respond mitogenically to PDGF (Shultz et al. 1988; Silver et al. 

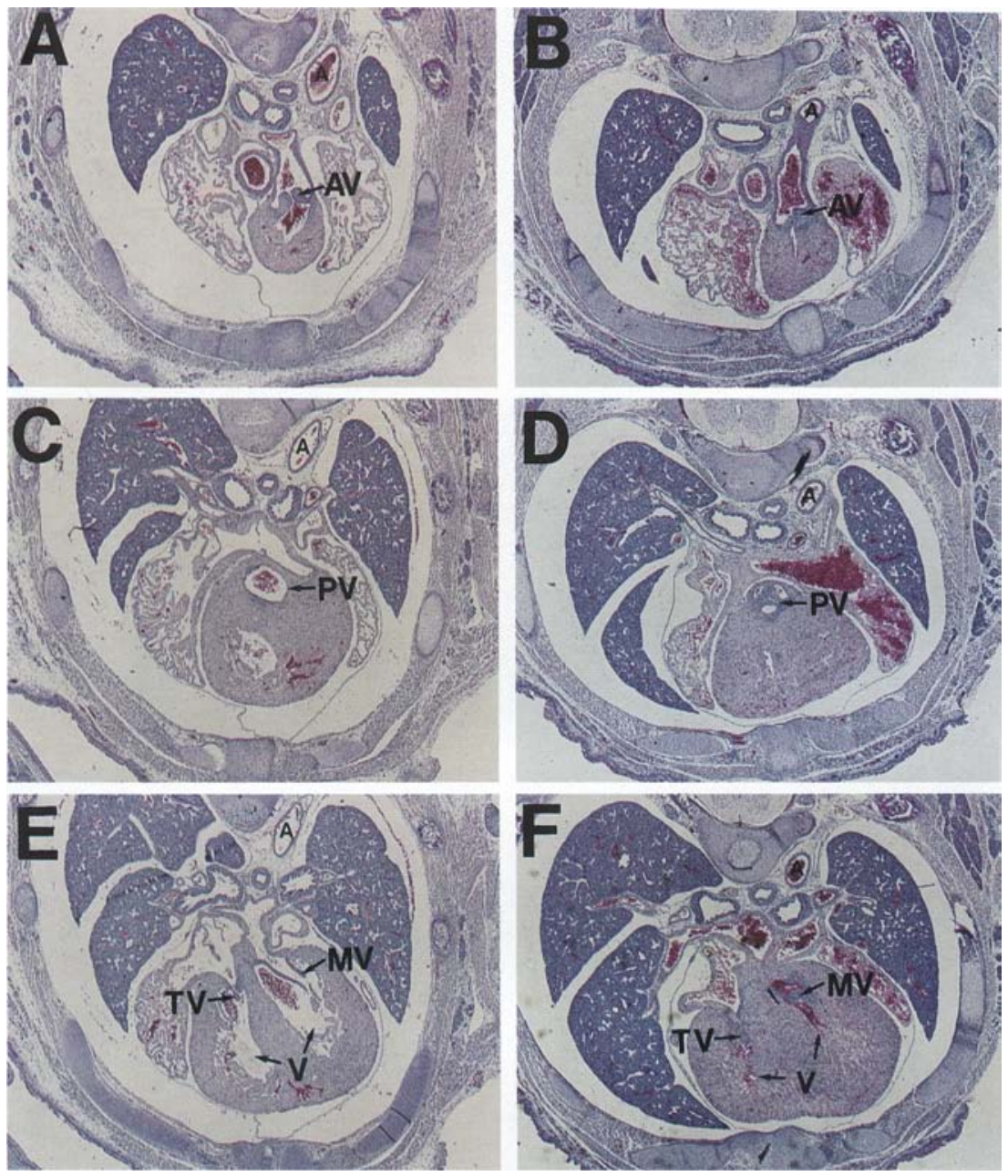

Figure 6. Heart and blood vessel dilation in PDGF B mutants. Appearance of the heart in E17.5 PDGF B mutant $(A, C, E)$ and heterozygous $|B, D, F|$ embryos. Sections were chosen to illustrate the appearance of the heart at the level of the aortic valve (AV) $(A, B)$ pulmonary artery valve (PV) $|C, D|$, and mitral (MV) and tricusp (TV) valves $\{E, F\rangle$ Note the dilated heart ventricles $(\mathrm{V})$ and the dilated aorta $(\mathrm{A})$ in the mutant embryo.

1989; Floege et al. 1991). The responses to the different PDGF isoforms vary, with $\mathrm{PDGF} B \mathrm{BB}$ and $\mathrm{AB}$ being far more mitogenic than PDGF AA (Floege et al. 1991; Madri and Marx 1992). PDGF-induced mitogenesis of mesangial cells therefore appears to occur via PDGFR $\beta$. This receptor subtype dominates on mesangial cells from several mammalian species (Fellström et al. 1989; Floege et al. 1991; Iida et al. 1991; Madri and Marx 1992; Alpers et al. 1993). Besides being mitogenic, PDGF also stimulates several other functions of mesangial cells, including directed migration (Barnes and Hevey 1990), the production of extracellular matrix components (Doi et al. 1992), contraction (Mene et al. 1987), and the production of cytokines (Lovett and Larsen 1988) and prostaglandins (Floege et al. 1990). Our results are consistent with the failure of the development of a glomerular mesangium in the kidneys of PDGF B mutant embryos. Such a failure may reside at the level of mesangial (or mesangial progenitor) cell migration, proliferation, function, survival, or combinations thereof. Some hints are provided by the expression patterns of PDGF $B$ and PDGFR $\beta$ in vivo in the fetal (Alpers et al. 1992) and the adult (Alpers et al. 1993) human kidneys. During glomerulo- genesis, PDGF B expression is localized to the differentiating epithelium of the glomerular vesicle /the corresponding stage of glomerulus development in PDGF B heterozygous and mutant embryos is shown in Fig. 4, D and $\mathrm{E}$, respectively) and PDGFR $\beta$ to interstitial and vascular structures (Alpers et al. 1992). At this stage, PDGF B may act as a paracrine factor, recruiting mesangial progenitor cells into the developing glomerulus. The relative lack of mesenchymal cells in the core of some of the glomerular vesicles in the PDGF B mutant embryos (Fig. $4 \mathrm{E})$ supports this concept. As the glomerular tuft forms, PDGF B expression switches from the epithelial to the mesangial cells, which at this stage also start expressing PDGFR $\beta$ (Alpers et al. 1992). Here, and as the tuft increases in size, PDGF B may have an autocrine action promoting further mesangial cell proliferation.

In spite of the virtual absence of mesangial cells in the PDGF B mutant kidney, electron microscopy revealed a morphologically normal basement membrane delineating the distended capillary loops of the mutant glomerular bodies (Fig. 5). This basement membrane is lined on its outer surface by podocytes with morphologically distinct pedicles and on its inner surface by endothelial 
Figure 7. Heart and blood vessel dilation in PDGF $B$ mutants. Appearance of the heart and the aorta in a PDGF B mutant embryo at E18.5. (A) Section showing the grossly dilated ventricles $(\mathrm{V})$ and right atrium (AT). Note also the dilated aorta (A). (B) Sections showing the hypertrabeculated ventricular wall. Note that the trabecular crypts of the right ventricle extend to the myopericardium $(\mathrm{P})$, creating a minimal wall thickness of one or a few cell layers $(C)$. (D) Subpericardial congested capillaries of the left ventricular wall. $(E, F)$ Appearance of the aortic wall. Note the dramatically elongated smooth muscle cells (SMC).
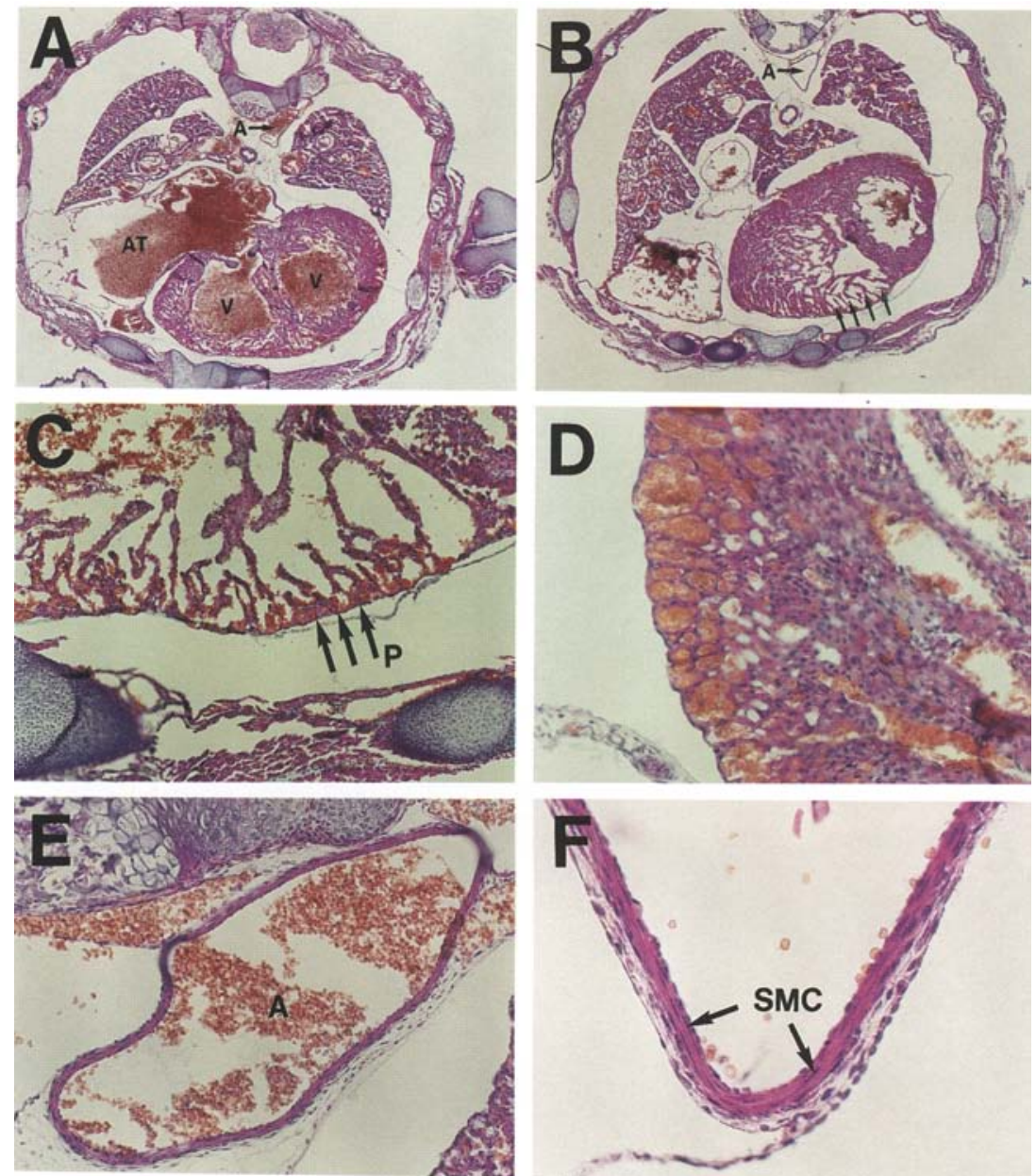

cells. Therefore, the structural features of the PDGF B mutant glomerular capillary wall do not seem to differ qualitatively from those of the normal glomerular capillary wall. Rather, the major discrepancy between normal and mutant glomeruli is that of their complexity; whereas the normal glomerular tuft consists of a detailed capillary network, the mutant counterpart contains no more than one or a few (dilated) capillary loops. An immediate structural consequence would be a greatly reduced glomerular filtration area. The notion that E19 mutant urinary bladders contain less urine than control bladders indicates that the mutant kidneys are functionally compromised.

Previous studies have suggested that the glomerular basement membrane has a dual cellular origin; the podocytes and the endothelial cells both contribute to its synthesis (Akblom 1981; Sariola et al. 1984). Basement membrane material is also produced by mesangial cells, but it is not known whether it will be incorporated in the glomerular basement membrane or solely contribute to the mesangial matrix. Because the mesangial matrix is focally attached to the glomerular basement membrane, it has been suggested that the mesangial cells are instrumental for the formation of the folded appearance of the basement membrane (Kriz and Kaissling 1992). The results presented in this and the accompanying paper (Soriano, this issue) clearly support these assumptions, but moreover, demonstrate that a morphologically normal glomerular basement membrane can be formed in the absence of mesangial cells.

\section{Arterial dilation suggests failure of smooth muscle cell function}

The arterial wall represents a structure in which physiological functions of PDGF B-containing molecules have been implicated from in vitro and in vivo studies. Aortic smooth muscle cells were among the first to be identified as targets for PDGF (Ross et al. 1974), responding in vitro with migration, mitogenesis, and function (e.g., extracellular matrix production) (for review, see Raines and Ross 1993). If PDGF B was involved in the regulation of smooth muscle cell proliferation during vasculogenesis, we would have expected a vascular wall phenotype to include hypoplasia of smooth muscle cells. This is apparently not the case (Fig. 6) and suggests that the ratelimiting effect of PDGF B on the vascular wall involves modulation of cellular functions rather than migration 
Table 2. Mean values and range of hematological parameters for E19 embryos of different genotype

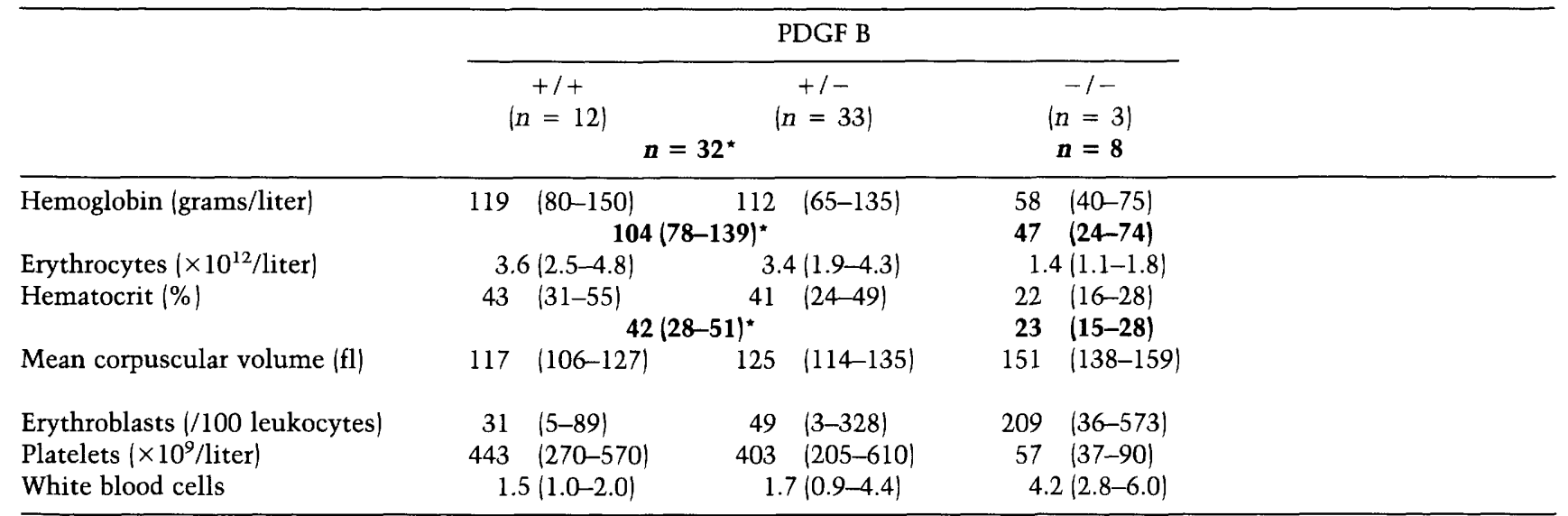

Values presented in boldface type were obtained by manual analysis of one series of E19 embryos. In this series, wild-type and heterozygous embryos were not discriminated and their values have been added $\left({ }^{\star}\right)$. The remaining values were obtained by analysis of a second series of E19 embryos with a Technicon $\mathrm{H} 1$ instrument.

or growth. General staining for elastin and collagen have not revealed any differences between control and mutant animals (results not shown). An intriguing possibility, therefore, is that the failing function relates to smooth muscle cell contraction. PDGF has been shown to be a powerful vasoconstrictor (Berk et al. 1986), and it is possible that during the development of some arteries, a certain degree of vasoconstriction is crucial for the achievement of a proper final vessel shape.

\section{The PDGF B mutant heart phenotype is similar in patch and WT-1 null allele homozygotes}

Low levels of PDGF B mRNA expression in the heart (Barrett and Benditt 1987) consistent with weak and diffuse staining with PDGF B antibodies (Raines and Ross 1993) have been reported. Likewise, heart tissue has demonstrated detectable expression of PDGFR $\beta$ and PDGFR $\alpha$ (Raines and Ross 1993). However, knowledge concerning the functional significance of this expression is lacking. Although the heart dilation is detectable in PDGF B mutant embryos as early as E16.5, the first intrauterine deaths occur at E17.5-E18.5, coinciding with severe cardiac dilation, generalized blood vessel dilation, and edema. This correlates in time with the normally occurring morphological differentiation of the heart muscle, seen mainly as increased trabeculation (Kaufman 1992), which has been interpreted as a preparation for the changed hemodynamic conditions after birth. Interestingly, dilation of the heart and its proximal arteries has been reported also in mouse embryos homozygous for the patch mutation; however, more severe and at an earlier time point (E10-E12) compared with the situation in the PDGF B mutants. patch is a deletion including the gene encoding PDGFR $\alpha$ and consequently, patch homozygotes are PDGFR $\alpha$-negative (Grüneberg and Truslove 1960; Morrison-Graham et al. 1992). The accompanying paper on the phenotype of the PDGFR $\beta$-deficient mouse (Soriano, this issue) reveals features closely similar to the ones described here. Hearts, however, appear normal in PDGFR $\beta$-negative embryos. The heart dilation of the PDGF B-negative embryos may therefore reflect a partial failure of PDGFR $\alpha$-dependent signaling, that is, that normally induced by PDGF BB and/or AB.

Early prenatal heart dilation has also been described in embryos homozygous for a disrupted Wilm's tumor suppressor gene (WT-1) (Kreidberg et al. 1993). The WT-1 protein has been shown to interact with the PDGF A promoter region, acting as a transcriptional repressor (Gashler et al. 1992; Wang et al. 1992). It needs to be studied further whether decreased PDGF activity (as a result of PDGF ligand or receptor deficiency) or putative increases in PDGF activity (as a potential result of deficiency of negative regulators of PDGF, such as WT-1), localized to the heart, may adversely affect cardiac function with the net result of cardiac dilation and failure.

\section{Why do the PDGF B mutants bleed?}

It is likely that the death of the majority (approximately three-fourths) of the PDGF B mutant embryos, which occurs just prior to birth, is related to the hemorrhages that appear at this time. In principle, the hematological picture may reflect primary changes in erythropoiesis and/or thrombopoiesis or it may be secondary to bleeding. In the latter scenario, the erythroblastosis would be secondary to the anemia and would reflect a compensatory increase in erythropoiesis and/or recruitment of erythroblasts from the spleen. However, preliminary results indicate that anemia and thrombocytopenia both occur in mutants already at E17.5, before any obvious signs of bleeding, but become more pronounced at E19 in correlation with the extent of bleeding (data not shown). Diffuse (and therefore difficult to detect) bleeding may occur at earlier stages and therefore, at present, we cannot discriminate between the different possibilities re- 
garding the etiology of the hematological changes seen in the mutant embryos.

The pronounced bleeding seen at E19 may relate to primary deficiencies in blood clotting, platelet number/ function, or vascular wall function/integrity. Preliminary tests suggest that the blood clotting time does not differ substantially between PDGF B mutants and controls (data not shown). The platelet numbers observed in some E19 embryos with apparent hemorrhages would not-although they are significantly reduced-be expected to cause bleeding in adult human beings; however, mice normally have higher platelet counts than humans, and the requirement for platelets in mouse embryos at the time of birth is unclear. Moreover, at present, we cannot exclude that the PDGF B mutant plates are functionally deficient. The idea of a primary blood vessel defect in PDGF B (this study) and PDGFR $\beta$ (Soriano, this issue) mutants would find support from the notion that normally, many vessel wall cells express PDGF B or PDGFR $\beta$ For example, capillary endothelial cells from certain tissues coexpress this ligand-receptor pair (Smits et al. 1989; Holmgren et al. 1991), and hence, may be dependent on their autocrine interaction for growth, migration, or function. A primary vascular wall deficiency may abrogate clotting functions or may lead to vessel rupture. It is intriguing that the bleeding in mutant embryos generally develops just prior to birth. Irrespective of the underlying primary defect, the triggering event may therefore by the increase in embryonic blood pressure expected to occur at this time.

\section{PDGF signaling in vivo}

The phenotype of the PDGF B-negative mouse embryos should reflect functions that are specific to the PDGF B-containing dimers (PDGF $\mathrm{BB}$ and PDGF $\mathrm{AB}$ ) and/or overlapping functions with other proteins (e.g., PDGF A) for which PDGF B is rate limiting (Fig. 8). Insight into such putative overlaps may be gained by comparing the individual knockout phenotypes for PDGF B, PDGF A, PDGFR $\beta$, and PDGFR $\alpha$ and combinations thereof. The analysis of mice having the PDGF A gene disrupted is under way in our laboratory. The phenotype of PDGFR $\beta$ -

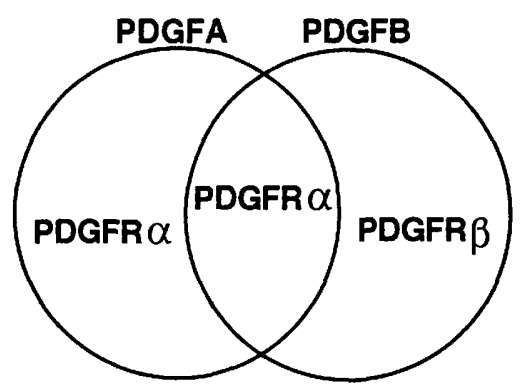

Figure 8. PDGF ligand receptor cross-reactivity. Schematic illustration of the overlap in receptor cross-reactivity between PDGF A and B. A putative similar functional overlap in vivo would implicate partial functional redundancy. deficient mice, presented in the accompanying paper (Soriano, this issue) includes kidney and hematological abnormalities that seem similar, if not identical, to those described here. It appears likely, therefore, that the development of the glomerular mesangium involves PDGF $\mathrm{BB}$ signaling through PDGFR $\beta$ dimers. In other organs (e.g., the heart), there may be differences, implying that other signaling pathways, such as PDGF $B B$ or $A B$ signaling through PDGFR $\alpha$, are of functional importance in vivo.

\section{Materials and methods}

Construction of a PDGF B targeting vector

A PDGF B clone was isolated from a 129 SV mouse genomic library (obtained from Stratagene) created in $\lambda$ FIX II. It was characterized and shown to contain the entire structural part of the PDGF B gene (data not shown). The targeting construct was built using standard recombinant DNA technology by joining three restriction fragments, as illustrated in Figure 1: a $5^{\prime}$ homologous segment, a phosphoglycerokinase (PGK)-neo cassette (obtained from Dr. J.K. Heath, Oxford, UK), and a 3' homologous segment. The design permitted the construct to be excised from the pBluescript vector using restriction sites naturally present in the gene. Thus, the homology of the $5^{\prime}$ and $3^{\prime}$ regions extended to the ends of the linearized targeting construct.

\section{Production of PDGF B mutant mice}

The targeting construct was excised from the vector with HindIII and XhoI and electroporated into E14.1 ES cells (provided by Dr. K. Rajewsky, Cologne, Germany) using a Bio-Rad Gene Pulser at the settings $240 \mathrm{~V} / 500 \mu \mathrm{F}$ in serum-free Dulbecco modified Eagle's medium (DMEM) supplemented with glucose, pyruvate, and nonessential amino acids (1:100); (medium and supplement stocks from GIBCO). The DNA concentration and ES cell density at electroporation was $60 \mu \mathrm{g} / \mathrm{ml}$ and $2 \times 10^{7}$ cells $/ \mathrm{ml}$, respectively. Electroporated cells were spread at a density of $2 \times 10^{5}$ cells $/ \mathrm{cm}^{2}$ onto a confluent layer of G418-resistant primary embryonic fibroblasts prepared from interleukin-4-neo transgenic mice (obtained from $\mathrm{K}$. Rajewsky) and cultured in DMEM containing $15 \%$ fetal calf serum, $0.1 \mathrm{mM}$ of $\beta$-mercaptoethanol and $1000 \mathrm{U} / \mathrm{ml}$ of leukemia inhibitory factor (LIF) (ESGRO). Selection in G418 (GIBCO, $200 \mu \mathrm{g} / \mathrm{ml}$ ) was started 1 day after electroporation and lasted for 10-13 days, at which point G418-resistant colonies could be identified and isolated. Such colonies were picked and expanded in 24-well plates and analyzed by Southern blotting. A replica of each clone was frozen prior to DNA preparation. PDGF B $+/$ - clones identified by Southern blotting were thawed and expanded during 5-7 days before microinjection. Blastocytes were harvested from C57Bl females at 3.5 days postcoitus and used for microinjection the same day. Pseudopregnant $\mathrm{C} 57 \mathrm{~B} / / \mathrm{CBA} \mathrm{F}_{1}$ females $(2.5$ day) were implanted with 10-12 injected blastocysts (10-15 ES cells/blastocyst). Chimeras were identified by the fur coat appearance of chinchilla and agouti in a background of black. Male chimeras were mated to $\mathrm{C} 57 \mathrm{Bl}$ females, and tail biopsies from agouti 129SV/C57Bl hybrid offspring were screened by Southern blot analysis to identify PDGF B $+/$ - genotypes. Such mice were then intercrossed to produce homozygous offspring carrying a mixed $129 \mathrm{SV} / \mathrm{C} 57 \mathrm{Bl}$ genetic background.

DNA analysis

DNA was prepared from adult biopsies and embryonic tissues by 
homogenization in $2 \mathrm{ml}$ of ice-cold buffer containing $50 \mathrm{mM}$ Tris, $100 \mathrm{mM} \mathrm{NaCl}$, and $100 \mathrm{~mm}$ EDTA ( $\mathrm{pH} 8.0$ ) using a Polytrone homogenizer, followed by the addition of $100 \mu \mathrm{l}$ of $20 \%$ SDS and $80 \mu \mathrm{l}$ of $10 \mathrm{mg} / \mathrm{ml}$ proteinase $\mathrm{K}$. Homogenates were then incubated overnight at $56^{\circ} \mathrm{C}$ followed by phenol/chloroform extraction and ethanol precipitation. Preparation of DNA from ES cells was performed by the addition of $0.5 \mathrm{ml}$ of lysis buffer ( $10 \mathrm{~mm}$ Tris, $1 \mathrm{~mm}$ EDTA, $100 \mathrm{~mm} \mathrm{NaCl}, 1 \%$ SDS, 500 $\mu \mathrm{g} / \mathrm{ml}$ of proteinase $\mathrm{K}$ ) to each culture (Falcon 24-well dishes) after removal of the culture medium and incubation at $37^{\circ} \mathrm{C}$ overnight. Phenol/chloroform extraction, precipitation of DNA, and Southern blotting onto Hybond $\mathrm{N}^{+}$membranes (Amersham) were performed using standard methods (Sambrook et al. 1989). A 1-kb genomic EcoRI-HindIII fragment, complementary to a region of the PDGF B locus immediately flanking the 5 ' homologous fragment of the targeting construct (Fig. 1B), was used as a probe to screen for homologous recombinants. In the recombinant allele, a new EcoRI site directed from the PGK-neo cassette defines the 3 ' end of the $10-\mathrm{kb}$ recombinant EcoRI fragment. The deletion of exon 4 in the targeted PDGF B allele was confirmed by hybridization to a probe complementary to and specific for mouse PDGF B exon 4 sequences. This probe was created by annealing the two oligonucleotides, 5'-GGG TCC CTG GCA GCA GCA GAG CCT GCT GTA ATC GCC GAG TGC AAG ACG CGC ACA GAG GTG TTC CAG ATC TCG CGG AAC CTC and 5'-GCG GTT ATT GCA GCA GCC GGA GCA GCG GTG CAC CTC CAC ACA GGG CGG CCA CAC CAG GAA GTT GGC GTT GGT GCG ATC GAT GAG GTT CCG $\mathrm{C}$, and synthesizing the complementary strands in the presence of $\left.{ }^{32} \mathrm{P}\right] \mathrm{dCTP}$, unlabeled dATP, dTTP, and dGTP and the Klenow fragment of DNA polymerase I. The resulting double-stranded DNA was denatured by boiling and used for subsequent hybridizations at high stringency.

\section{Histological analysis}

Embryos were processed for routine histology by fixation in buffered formalin followed by paraffin embedding and sectioning. Sections were stained with Ehrlich's hematoxylin and eosin, periodic acid-Schiff, elastin van Gieson, aldehyde fuchsin, and sirius red according to standard protocols (Smith and Bruton 1978). For electron microscopy, kidney specimens were fixed overnight at $4^{\circ} \mathrm{C}$ in $3 \%$ glutaraldehyde in $0.1 \mathrm{M}$ cacodylate buffer $(\mathrm{pH} 7.2)$ and postfixed at room temperature in $1 \%$ osmium tetroxide in $0.1 \mathrm{M}$ cacodylate buffer. After fixation, the specimen were rinsed in buffer, "en block" stained with $1 \%$ uranyl acetate in $50 \%$ ethanol overnight, dehydrated in graded series of ethanol, and finally embedded in agar 100 epoxy resin. Semithin sections $(1 \mu \mathrm{m})$ were stained with touluidine blue for light microscopy, and ultrathin sections $(60 \mathrm{~nm})$ were contrasted with lead citrate and examined using a Philips electron microscope.

\section{Hematology}

Peripheral blood cell counts and hemoglobin determinations were analyzed manually or by use of a Technicon $\mathrm{Hl}$ instrument. For the latter, $30 \mu \mathrm{l}$ of blood was collected following decapitation of the embryos and added into microtiter EDTA tubes (Becton Dickinson) containing $120 \mu \mathrm{l}$ of phosphate-buffered saline. Differential counting of 100-200 nucleated cells was performed on May-Grünwald-Giemsa-stained blood films.

\section{Acknowledgments}

The technical contributions of Benita Andersson /electron mi- croscopy) and Frank Bittkowski (photography) are gratefully acknowledged. We also thank Philippe Soriano for sharing results prior to publication and Charles Alpers, Peter Ekblom, and Philippe Soriano for helpful discussions. This study was supported by grants from the Swedish Cancer Foundation.

The publication costs of this article were defrayed in part by payment of page charges. This article must therefore be hereby marked "advertisement" in accordance with 18 USC section 1734 solely to indicate this fact.

\section{References}

Abboud, H.E., E. Poptic, and P. DiCorleto. 1987. Production of platelet-derived growth factor-like protein by rat mesangial cells in culture. J. Clin. Invest. 80: 675-683.

Alpers, C.E., R.A. Seifert, K.L. Hudkins, R.J. Johnson, and D.R. Bowen-Pope. 1992. Developmental patterns of PDGF B-chain, PDGF receptor and $\alpha$-actin expression in human glomerulogenesis. Kidney Int. 42: 390-399.

- 1993. PDGF-receptor localizes to mesangial, parietal epithelial, and interstitial cells in human and primate kidney. Kidney Int. 43: 286-294.

Balk, S.D. 1971. Calcium as a regulator of the proliferation of normal, but not of transformed, chicken fibroblasts in a plasma-containing medium. Proc. Natl. Acad. Sci. 68: 271285.

Barnes, J.L. and K.A. Hevey. 1990. Glomerular mesangial cell migration in response to platelet-derived growth factor. $L a b$. Invest. 62: 379-382.

Barrett, T.B. and E.P. Benditt. 1987. sis (platelet-derived growth factor B chain/gene transcript levels are elevated in human atherosclerotic lesions compared to normal artery. Proc. Natl. Acad. Sci. 84: 1099-1103.

Berk, B.C., R.W. Alexander, T.A. Brock, M.A. Gimbrone Jr., and R.C. Webb. 1986. Vasoconstriction: A new activity for platelet-derived growth factor. Science 232: 87-90.

Betsholtz, C. 1993. The PDGF genes and their regulation. In Biology of platelet-derived growth factor, 5 (ed. B. Westermark, and C. Sorg), pp. 11-30. Karger, Basel, Switzerland.

Busch, C., $\AA$. Wasteson, and B. Westermark. 1976. Release of a cell growth promoting factor from human platelets. Thromb. Res. 8: 493-500.

Doi, T., H. Vlassara, M. Kirstein, Y. Yamada, G.E. Striker, and L.J. Striker. 1992. Receptor-specific increase in extracellular matrix production in mouse mesangial cells by advanced glycosylation end products is mediated via platelet-derived growth factor. Proc. Natl. Acad. Sci. 89: 2873-2877.

Ekblom, P. 1981. Formation of basement membranes in the embryonic kidney: An immunohistochemical study. J. Cell. Biol. 91: 1-10.

Fellström, B., L. Klareskog, C.-H. Heldin, E. Larsson, L. Rönnstrand, L. Terracio, G. Tufveson, J. Wahlberg, and K. Rubin. 1989. Platelet-derived growth factor receptors in the kidney--Upregulated expression in inflammation. Kidney Int. 36: 1099-1102.

Floege, J., N. Topley, and K. Wessel. 1990. Monokines and platelet-derived growth factor modulate protanoid production in growth arrested, human mesangial cells. Kidney Int. 37: 859-869.

Floege, J., N. Topley, J. Hoppe, T.B. Barrett, and K. Resch. 1991. Mitogenic effect of platelet-derived growth factor in human glomerular mesangial cells: Modulation and/or suppression by inflammatory cytokines. Clin. Exp. Immunol. 86: 334341.

Gashler, A.L., D.T. Bonthron, S.L. Madden, F.J. Raucher III, T. 
Collins, and V.P. Sukhatme. 1992. Human platelet-derived growth factor A chain is transcriptionally repressed by the Wilm's tumor suppressor WT1. Proc. Natl. Acad. Sci. 89: 10984-10988.

Giese, N.A., K.C. Robbins, and S.A. Aaronson. 1987. The role of individual cysteine residues in the structure and function of the v-sisgene product. Science 236: 1315-1318.

Gouston, A.S., C. Betsholtz, S. Pfeifer-Ohlsson, H. Persson, J. Rydnert, M. Bywater, G. Holmgren, C.-H. Heldin, B. Westermark, and R. Ohlsson. 1985. Co-expression of the sis and myc proto-oncogenes in developing human placenta suggests autocrine control of trophoblast growth. Cell 41: 301312.

Grotendorst, G.R., T. Chang, H.E.J. Seppä, H.K. Kleinman, and G.R. Martin. 1982. Platelet-derived growth factor is a chemoattractant for vascular smooth muscle cells. I. Cell. Physiol. 113: 261-266.

Gruneberg, H. and G.M. Truslove. 1960. Two closely linked genes of the mouse. Genet. Res. 1: 69-90.

Gullberg, D., A. Tingström, A.-C.Thuresson, L. Olsson, L. Terracio, T.K. Borg, and K. Rubin. 1990. $\beta 1$ Integrin-mediated collagen gel contraction is simulated by PDGF. Exp. Cell Res. 186: 264-272.

Hart, C.E., J.W. Forstrom, J.D. Kelly, R.A. Seifert, R.A. Smith, R. Ross, M.J. Murray, and D.F. Bowen-Pope. 1988. Two classes of PDGF receptors recognize different isoforms of PDGF. Science 240: 1529-1531.

Heldin, C.-H. and B. Westermark. 1989. Platelet-derived growth factor: Three isoforms and two receptor types. Trends Genet. 5: 108-111.

- 1990. Platelet-derived growth factor: Mechanism of action and possible in vivo function. Cell Regul. 1: 555-566.

Heldin, C.H., G. Bäckström, A. Östman, A. Hammacher, L. Rönnstrand, K. Rubin, M. Nistér, and B. Westermark. 1988. Binding of different dimeric forms of PDGF to human fibroblasts: Evidence for two separate receptor types. EMBO J. 7: 1387-1394.

Heldin, C.-H., A. Ernlund, C. Rorsman, and L. Rönnstrand. 1989. Dimerization of B-type platelet-derived growth factor receptors occurs after ligand binding and is closely associated with receptor kinase activation. I. Biol. Chem. 264: 8905-8912.

Heldin, C.-H., A. Östman, and B. Westermark. 1993. Structure of platelet-derived growth factor: Implications for functional properties. Growth Factors 8: 245-252.

Holmgren, L., A. Glaser, S. Pfeifer-Ohlsson, and R. Ohlsson. 1991. Angiogenesis during human extraembryonic development involves the spatiotemporal control of PDGF ligand and receptor gene expression. Development 113: 749-754.

Iida, H., R. Seifert, C.E. Alpers, R.G.K. Gronwald, P.E. Phillips, P. Pritlz, K. Gordon, A.M. Gown, R. Ross, D.F. Bowen-Pope, and R.J. Johnson. 1991. Platelet-derived growth factor (PDGF) and PDGF receptors are induced in mesangial proliferative nephritis in the rat. Proc. Natl. Acad. Sci. 88: 6560-6564.

Kaufman, M.H. 1992. The atlas of mouse development. Academic Press, London, UK.

Kreidberg, J.A., H. Sariola, J.M. Loring, M. Maeda, J. Pelletier, D. Housman, and R. Jaenisch. 1993. WT-1 is required for early kidney development. Cell 74: 679-691.

Kriz, W. and B. Kaissling. 1992. Structural organization of the mammalian kidney. In The kidney: Physiology and pathophysiology, 2nd ed. (ed. D.W. Seldin and G. Giebisch), pp. 707-777. Raven Press, New York.

Kuhn, R., K. Rajewsky, and W. Müller. 1991. Generation and analysis of interleukin-4 deficient mice. Science 254: 707-
710.

Lovett, D.H. and A. Larsen. 1988. Cell cycle-dependent interleukin 1 gene expression by cultured glomerular mesangial cells. J. Clin. Invest. 82: 115-122.

Madri, J.A. and M. Marx. 1992. Matrix composition, organization and soluble factors: Modulators of microvascular cell differentiation in vitro. Kidney Int. 41: 560-565.

Majack, R.A., S.C. Cook, and P. Borstein. 1985. Platelet-derived growth factor and heparin-like glycosaminoglycans regulate thrombospondin synthesis and deposition in the matrix by smooth muscle cells. I. Cell Biol. 101: 1059-1070.

Mene, P., H.E. Abboud, G.R. Dubyak, A. Scarpa, and M.J. Dunn. 1987. Effects of PDGF oninositol phosphates, $\mathrm{Ca}^{2+}$, and contraction of mesangial cells. Am. J. Physiol. 253: F458-F463.

Mercola, M., D.A. Melton, and C.D. Stiles. 1988. Platelet-derived growth factor A chain is maternally encoded in Xenopus embryos. Science 241: 1223-1225.

Morrison-Graham, K., G.C. Schatteman, T. Bork, D.F. BowenPope, and J.A. Weston. 1992. A PDGF receptor mutation in the mouse (patch) perturbs the development of a non-neuronal subset of neural crest-derived cells. Development 115: 133-142.

Oefner, C., A. D'Arcy, F.K. Winkler, B. Eggiman, and M. Hosang. 1992. Crystal structure of human platelet-derived growth factor BB. EMBO I. 11: 3921-3926.

Orr-Urtreger, A. and P. Lonai. 1992. Platelet-derived growth factor-A and its receptor are expressed in separate but adjacent cell layers of the mouse embryo. Development 115: 10451058.

Östman, A., M. Andersson, G. Bäckström, U. Hellman, C. George-Nascimento, B. Westermark, and C.-H. Heldin. 1992. Assignment of interchain disulphide bonds in plateletderived growth factor (PDGF) and evidence for agonist activity of monomeric PDGF. J. Biol. Chem. 267: 11260-11266.

Owen, A.J.I., R.P. Geyer, and H.N. Antoniades. 1982. Human platelet-derived growth factor stimulates amino acid transport and protein synthesis by human diploid fibroblasts in plasma-free media. Proc. Natl. Acad. Sci. 79: 3203-3207.

Raff, M.C. 1989. Glial cell diversification in the rat optic nerve. Science 243: 1450-1455.

Raines, E. and R. Ross. 1993. Platelet-derived growth factor in vivo. In Biology of platelet-derived growth factor, 5 (ed. B. Westermark and C. Sorg|, pp. 74-114. Karger, Basel, Switzerland.

Raines, E.W., D.F. Bowen-Pope, and R. Ross. 1990. Platelet-derived growth factor. In Handbook of experimental pharmacology. Peptide growth factors and their receptors, 95, part I (ed. M.B. Sporn and A.B. Roberts), pp. 173-262. SpringerVerlag, Heidelberg, Germany.

Rappolee, D.A., C.A. Brenner, R. Schultz, D. Mark, and Z. Werb. 1988. Developmental expression of PDGF, TGF- $\alpha$, and TGF- $\beta$ genes in preimplantation mouse embryos. Science 241: 1823-1825.

Richardson, W.D. 1990. The oligodendrocyte-type-2 astrocyte lineage. Sem. Neurosci. 2: 445-454.

Ross, R., J.A. Glomset, B. Kariya, and L. Harker. 1974. A platelet-dependent serum factor that stimulates the proliferation of arterial smooth muscle cells in vitro. Proc. Natl. Acad. Sci. 71: 1207-1210.

Ross, R., E.W. Raines, and D.F. Bowen-Pope. 1986. The biology of platelet-derived growth factor. Cell 46: 155-169.

Sambrook, J., E.F. Fritsch, and T. Maniatis. 1989. Molecular cloning: A laboratory manual, 2nd ed. Cold Spring Harbor Laboratory, Cold Spring Harbor, New York.

Sariola, H., R. Timpl, K. von der Mark, R. Mayne, J.M. Fitch, T.F. Linsenmayer, and P. Ekblom. 1984. Dual origin of glo- 
merular basement membrane. Dev. Biol. 101: 86-96.

Sasahara, M., J.W.U. Fries, E.W. Raines, A.M. Gown, L.E. Westrum, M.P. Frosch, D.T. Bonthron, R. Ross, and T. Collins. 1991. PDGF B-chain in neurons of the central nervous system, posterior pituitary and in a transgenic model. Cell 64: 217-227.

Sasahara, A., J.N. Kott, M. Sasahara, E.W. Raines, R. Ross, and L.E. Westrum. 1992. Platelet-derived growth factor B-chainlike immunoreactivity in the developing and adult rat brain. Dev. Brain Res. 68: 41-53.

Sauer, M.K. and D.J. Donoghue. 1988. Identification of nonessential disulfide bonds and altered conformations in the $\mathrm{v}$-sis protein, a homolog of the B chain of platelet-derived growth factor. Mol. Cell. Biol. 8: 1011-1018.

Seifert, R.A., C.E. Hart, P.E. Philips, J.W. Forstrom, R. Ross, M. Murray, and D.F. Bowen-Pope. 1989. Two different subunits associate to create isoform-specific platelet-derived growth factor receptors. J. Biol. Chem. 264: 8771-8778.

Shultz, P.J., P.E. DiCorleto, B.J. Silver, and H.E. Abboud. 1988. Mesangial cells express PDGF mRNAs and proliferate in response to PDGF. Am. I. Physiol. 255: F674-F684.

Siegbahn, A., A. Hammacher, B. Westermark, and C.-H. Heldin. 1990. Differential effects of the various isoforms of plateletderived growth factor on chemotaxis of fibroblasts, monocytes and granulocytes. I. Clin. Invest. 85: 916-920.

Silver, B.J., F.E. Jaffer, and H.E. Abboud. 1989. Platelet-derived growth factor synthesis in mesangial cells: Induction by multiple peptide mitogens. Proc. Natl. Acad. Sci. 86: 10561060.

Smith, A. and J. Bruton. 1978. A colour atlas of histological staining techniques. Wolfe medical atlases-18. Wolfe Medical Publications Ltd., London, UK.

Smits, A., M. Hermansson, M. Nistér, I. Karnushina, C.-H. Heldin, B. Westermark, and K. Funa. 1989. Rat brain capillary endothelial cells express functional PDGF B-type receptors. Growth Factors 2: 1-8.

Soriano, P. 1994. Abnormal kidney development and hematological disorders in PDGF $\beta$-receptor mutant mice. Genes \& Dev. (this issue).

Wang, Z.Y., S.L. Madden, T.F. Deuel, and F. Raucher III. 1992. The Wilm's tumor gene product, WTl, represses transcription of the platelet-derived growth factor A-chain gene. $J$. Biol. Chem. 267: 21999-22002.

Yeh, H.-J., K.G. Ruit, Y.-X. Wang, W.C. Parks, W.D. Snider, and T.F. Deuel. 1991. PDGF A-chain gene is expressed by mammalian neurons during development and in maturity. Cell 64: $209-216$. 


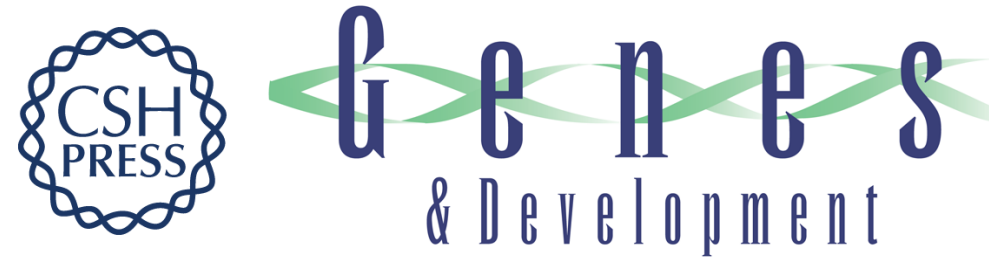

\section{Mice deficient for PDGF B show renal, cardiovascular, and hematological abnormalities.}

P Levéen, M Pekny, S Gebre-Medhin, et al.

Genes Dev. 1994, 8:

Access the most recent version at doi:10.1101/gad.8.16.1875

References This article cites 55 articles, 25 of which can be accessed free at:

http://genesdev.cshlp.org/content/8/16/1875.full.html\#ref-list-1

License

Email Alerting

Service

Receive free email alerts when new articles cite this article - sign up in the box at the top right corner of the article or click here.

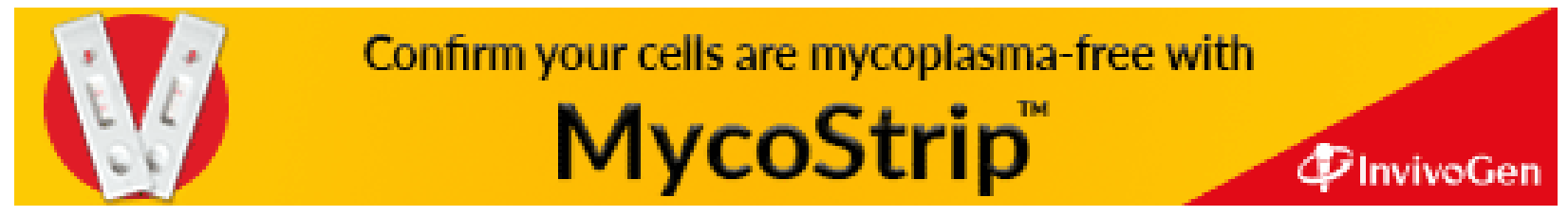

